Historic, archived document

Do not assume content reflects current scientific knowledge, policies, or practices. 

CONTRIBUTIONS TOWARD

A FIORA OF NEVADA. NO. 19.

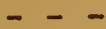

LENTIBUIARIACEAE OF NEVADA

by

O. N. FREEMAIT

December 6,1940

Issued by

The Division of Plant Exploration and Introduction, Burcau of Plant Industry,

U. S. Department of Agriculture,

Washington, D. C.

Work Projects Administration of Neveda, Projects, 0. P. 65-2-04-13, W. F. 658;

O. P. 165-2-04-21, V. P. 752 .

Collaborator

University of Novada.

Address all queries concerning this nublication to the Division of Plant Exploration and Introduction, Bureau of Plant Industry, U. S. Department of Agriculture, Washington, D. C. 


\section{CONTRIBUTIONS TOWARD}

A FLORA OF INEVADA. NO. 19.

LENTIBULARIACEAE OF NEVADA

by

O. M. FREEMAN

December 6, 1940

\section{Is sued by}

The Division of Plant Exploration and Introduction, Bureau of Plant Industry,

U. S. Department of Agriculture, Washington, D. C.

Work Projects Administration of Nevada,

Projects, 0. P. 65-2-04-13, w. P. 658;

o. P. 165-2-04-21, W. P. 752 .

Collaborator

University of Nevada.

Address all queries concerning this publication to the Division of Plant Exploration and Introduction, Bureau of Plant Industry, U. S. Department of Agriculture, Washington, D. C. 



\section{IENTIBULARIACEAE OF NEVADA.}

By O. M. Freeman

Ours a single genus of slender, scapose, aquatic or marsh plants. Calyx 2-lipped; corolla 2-lipped, lower lip 3-lobed and spurred at the base. Stamens 2 with l-celled anther; ovary superior, l-celled with a free central placenta. Style I, with a 2-cloft stigma. Fruit a 2-valved capsule with numerous seeds.

\section{UTRICULARIA I. Bladderwort.}

Bladder-bearing capillary-divided leaves. Scapes with small auricled scales and 1 to several flowered. Iips of the calyx entire. The projecting palate on the lower lip of the corolla often closing tho throat. The bladders are apparently for keeping the plant afloat at flowering time and to trap minute water animals which enter small openings and are unable to free themselves. Flowers yellow in our species.

\section{KEY TO SPECIES}

Bladders numerous, spur conspicuous, corolla about $10 \mathrm{~mm}$. broad.

1. U. vulgaris.

Bladders few, spur short and inconspicuous or almost none, corolla $6 \mathrm{~mm}$ or less broad .......... 2. U. minor. 

1. UTRICULARIA VULGARIS I. Sp. P1. 18. 1753.

In shallow quiet water. Widely distributed in North America. To be expected in any quiet or slowly moving fresh water throughout the state.

Nevada: Churchill County. Probably also in Washoe and Pershing Counties.

2. UTRICULARIA MINOR L. Sp. P1. 18. 1753.

No specimen of this species from Nevada seen by the writer, but it probably occurs in shallow, quiet waters, especially in the western part of the State. 
